\title{
Maturity and Storage Quality of 'Concorde' Pears
}

\author{
S.R. Drake, ${ }^{1}$ E.A. Mielke, ${ }^{2}$ and \\ D.C. Elfving ${ }^{3}$
}

Additional IndeX words. Postharvest, controlled atmosphere, Pyrus communis

Summary. 'Concorde' pears from three plantings were harvested at various maturities, stored in regular (RA) or controlled atmosphere (CA) storage and their quality evaluated. Starting at a firmness of $57.0 \mathrm{~N}$ (12.81 lbf), 'Concorde' pears can be harvested over a period of 14 days with no loss in quality and be good candidates for either RA or CA storage. A 14-day delay in harvest resulted in a one box size increase. Regardless of the time of harvest, 'Concorde' pears can be stored in RA for periods not to exceed 90 days. RA storage beyond 90 days resulted in reduced appearance, poor pedicel condition, and enhanced internal breakdown. Early harvest should be considered when RA storage is expected to exceed 90 days; however astringency may develop. Regardless of harvest, 'Concorde' pears can be stored for $\mathbf{1 8 0}$ days in CA with no quality loss, particularly if the CA composition is $1.5 \%$ oxygen $\left(\mathrm{O}_{2}\right)$ and $1.0 \%$ carbon dioxide $\left(\mathrm{CO}_{2}\right)$. Internal breakdown can be a problem in CA if the $\mathrm{CO}_{2}$ exceeds $1.0 \%$. Low $\mathrm{O}_{2}(<1.5 \%) \mathrm{CA}$ is not recommended for 'Concorde' pears.

$\mathrm{C}$ oncorde pear production has expanded in recent years, particularly in the Pacific northwestern U.S., with nurseries reporting sales of about 150,000 trees through 2003.

This 'Comice' by 'Conference' cross has an intense, sweet flavor. It is edible as a firm, crisp pear immediately out of storage, and will ripen to a smooth, buttery texture. Initial

The authors express appreciation to the Washington Tree Fruit Research Commission for grant funds partially supporting this study.

${ }^{1}$ Research horticulturist, USDA,ARS-TFRL, $1104 \mathrm{~N}$. Western Ave., Wenatchee, WA 98801.

${ }^{2}$ Horticulturist, Oregon State Univ., Mid-Columbia Agriculture Research. \& Extension Center, 3005 Exp. Station Dr., Hood River, OR 97031

${ }^{3}$ Professor and horticulturist, Washington State Univ., Tree Fruit Research and Extension Center, $1100 \mathrm{~N}$. Western Ave., Wenatchee, WA 98801. 
studies suggest that 'Concorde' may have inherited 'Conference's sensitivity to $\mathrm{CO}_{2}$ and ethylene (Testoni et al., 2002 ) and low boron induced physiological disorders (Xuan et al., 2002) during storage.

Additionally, some samples stored for 4 months have developed an astringency that was observed in England (A.D. Webster, personal communication).

Maturity at harvest has a major influence on the storage quality of pears (Talley, 1989). At present, days from full bloom, color, firmness, soluble solids, starch, and size are all used as maturity indices, with firmness being the most prevalent (Drake, 1989; Meheriuk, 1988; Tvergyak, 1985), but starch is also considered important (Kvale, 1990). Cultivar, maturity, and storage quality have been the topics of many research projects (Chen and Mellenthin, 1981; Chen et al., 1994; Fallahi and Larsen, 1981; Hansen and Mellenthin, 1979; Meheriuk, 1989; Looney, 1972; Sugar and Powers, 1994; Sugar and Lombard, 1989). The goal of commercial handling and storage practices for pears is to maintain quality fruit throughout the marketing season and reduce the amount of cullage that may develop during storage and handling (Hansen and Mellenthin, 1979). Little or no information is available concerning the maturity and subsequent storage quality of 'Concorde' pears. If production of this cultivar is to continue and increase, information concerning maturity and storage potential must be determined. The objective of this study was to determine storage potential and its relationship to various maturities of 'Concorde' pear.

\section{Materials and methods}

Fruit sources. Three plantings in the Pacific northwestern U.S. were utilized as sources of fruit for these experiments. The first (WA-1) was a commercial block on a cooperating grower's farm planted in 1994 in Cashmere, Wash., on Bartlett Seedling rootstock. The second (OR-1) was planted in 1995 at the Oregon State University Mid-Columbia Agricultural Research and Extension Center (MCAREC) in Hood River, Ore., on Bartlett Seedling rootstock, and the third was a block at MCAREC planted in 1997 on Old Home x Farmingdale 87 (OHxF 87) rootstock.

Flesh fiRmness, SOLUble SOLIDS,
TOTAL ACID, FRUIT COLOR, INTERNAL BREAKDOWN, AND CA STUDIES. Fruit for these studies were obtained from the WA-I planting only. In each of 3 years, 24 trees of uniform size and fruit load were selected and divided into eight replicate units of three trees each. When fruit reached commercial harvest maturity (57.0 N flesh firmness), four replicates were harvested; the remaining four replicates were harvested $14 \mathrm{~d}$ later. At each harvest during the first year, 140 pears were harvested from each unit or 560 pears/harvest. During the second and third years, 120 pears were harvested from each replicate or 480 pears/harvest. Ten pears from each harvested unit were evaluated immediately after each harvest to define maturity (firmness, external color, soluble solids, and acidity). Sixty pears from each unit were placed in regular atmosphere (RA) storage and 80 pears each in four different, controlled-atmosphere $(\mathrm{CA})$ storages $\left(1.5 \% \mathrm{O}_{2}+0.5 \%\right.$ $\mathrm{CO}_{2}, 1.5 \% \mathrm{O}_{2}+1.0 \% \mathrm{CO}_{2}, 1.5 \% \mathrm{O}_{2}+$ $3.0 \% \mathrm{CO}_{2}$, or $\left.1.5 \% \mathrm{O}_{2}+5.0 \% \mathrm{CO}_{2}\right)$ at $1{ }^{\circ} \mathrm{C}\left(33.8^{\circ} \mathrm{F}\right)$. After one season, the CA of $1.5 \% \mathrm{O}_{2}+5.0 \% \mathrm{CO}_{2}$ treatment was eliminated due to excessive core breakdown of the fruit.

After 45,90 , or 150 d RA storage and 90 or $180 \mathrm{~d}$ CA storage, pears were removed from storage and quality determined on 10 pears immediately after removal from storage and on an additional 10 pears following $7 \mathrm{~d}$ of ripening at $20^{\circ} \mathrm{C}\left(68.0^{\circ} \mathrm{F}\right)$. Quality factors evaluated were firmness, external and internal color, soluble solids concentration (SSC), titratrable acidity (TA), general appearance, visually rated disorders (scald, shrivel), and rot. Firmness was determined using the texture analyzer (modelTA-XT2; Texture Technologies, Scarsdale, N.Y.), equipped with a 7.7$\mathrm{mm}(0.30$-inch $)$ probe. External and internal color was determined with a colorimeter (ColorFlex, model 45/0; Hunter Assoc., Reston, Va.) using the $\mathrm{L}^{*}, \mathrm{a}^{*}, \mathrm{~b}^{*}$ system and calculated hue values (Hunter and Harold, 1987). SSC and TA were determined from a composite of juice expressed from longitudinal slices from each of the 10 fruits. An Abbé type refractometer with a sucrose scale calibrated at $20{ }^{\circ} \mathrm{C}$ was used to determine SSC. TA was measured with a titrator (model TTT85; Radiometer, Copenhagen, Denmark). Acids were titrated to $\mathrm{pH} 8.2$ with 0.1 $\mathrm{N}$ sodium hydroxide and expressed as percent malic acid.
Following RA and CA storage, pears from each harvest and storage condition were evaluated for general appearance, scald, pedicel (stem) condition and physiological disorders (scald) using a scale of $1=$ none/excellent, 2 = slight $/$ good, $3=$ moderate $/$ fair and $4=$ extreme $/$ poor by two laboratory personnel familiar with pear disorders and amounts reported in percentage of total fruit. All data were analyzed as a completely randomized design with MSTAT-C 1988 using harvest units as replications. Harvest date was the main plot with storage and ripening as subplots. Means showing a significant $F$ test were separated using Tukey's honestly significant difference (HSD) test.

FRUIT ASTRINGENCY, FLAVOR, AND TEXTURE. Fruit for these studies was obtained from all three locations. Each planting was divided into thirds (replications), and four boxes (30 fruit each) randomly selected at each harvest and packed in cardboard boxes with polyethylene liners without any postharvest treatment. Due to a lack of consistent 'Concorde' flesh firmness readings near harvest, the onset of commercial CA 'd'Anjou' harvest [66.7 N (15.0 lbf)] was selected as the reference date for first harvest. Subsequent harvests were made 14 and $28 \mathrm{~d}$ after the reference date.

One box of fruit from each location and harvest was placed RA at -1.0 ${ }^{\circ} \mathrm{C}\left(30.20^{\circ} \mathrm{F}\right)$ in for 1,2 , or 4 months, or in CA for 4 or 6 months. The CA fruit was cooled to $-1.0{ }^{\circ} \mathrm{C}$ in $\mathrm{RA}$ until all harvests had had been made. It was then transferred to low oxygen CA $\left(1.0 \% \mathrm{O}_{2}+<0.1 \% \mathrm{CO}_{2}\right)$ at -1.0 ${ }^{\circ} \mathrm{C}$ for 4 months (total time in storage approached 5 months). Low oxygen conditions were achieved within $5 \mathrm{~d}$ by flushing the room with nitrogen gas $\left(\mathrm{N}_{2}\right)$ from a nitrogen generator for 48 $\mathrm{h}\left(\right.$ to $1.5 \% \mathrm{O}_{2}$ ) and allowing normal respiration to remove the final $0.5 \%$ $\mathrm{O}_{2}$. Oxygen levels were maintained at $1.0 \%$ by periodically bleeding in $100 \%$ $\mathrm{O}_{2}$. The level of $\mathrm{CO}_{2}$ was maintained at $<0.1 \%$ by adding hydrated lime to the storage at a rate of $1.02 \mathrm{~kg}(2.25 \mathrm{lb})$ lime per $20.4 \mathrm{~kg}(45 \mathrm{lb})$ fruit.

Following each storage period, the fruit was ripened for $7 \mathrm{~d}$ at $20.0^{\circ} \mathrm{C}$. Following ripening, six fruit were selected at random from each box, and individually evaluated (two to five panelists) for astringency, flavor and texture using a 10 point scale where $0=$ none/poorest and $9=$ most $/$ best.

The data were analyzed as a split, 
Table 1. Harvest quality attributes for 'Concorde' pear harvested at two levels of maturity.

\begin{tabular}{|c|c|c|c|c|c|c|c|c|}
\hline \multirow{2}{*}{$\begin{array}{l}\text { Maturity } \\
\text { level }\end{array}$} & \multirow{2}{*}{$\begin{array}{c}\text { Firmness }^{\mathrm{z}} \\
(\mathrm{N})\end{array}$} & \multirow{2}{*}{$\begin{array}{c}\text { SSC }^{y} \\
(\%)\end{array}$} & \multirow{2}{*}{$\begin{array}{l}\text { TA }^{\mathrm{x}} \\
(\%)\end{array}$} & \multicolumn{4}{|c|}{ Peel color } & \multirow{2}{*}{$\begin{array}{l}\text { Wt } \\
(\mathrm{g})^{\mathrm{w}}\end{array}$} \\
\hline & & & & $\mathrm{L}^{*}$ & $a^{*}$ & $\mathrm{~b}^{*}$ & Hue & \\
\hline $\mathrm{I}^{\mathrm{v}}$ & $57.2 \mathrm{a}^{\mathrm{t}}$ & $14.9 \mathrm{~b}$ & $0.18 \mathrm{a}$ & $50.7 \mathrm{a}$ & $-7.4 \mathrm{a}$ & $23.0 \mathrm{a}$ & 107.9 a & $211 \mathrm{~b}$ \\
\hline
\end{tabular}

${ }^{2} 1.0 \mathrm{~N}=0.225 \mathrm{lbf}$

ySC $=$ soluble solids concentration.

$\mathrm{x}$ TA = titratable acidity expressed as percent malic acid

${ }^{\mathrm{w}} \mathrm{l} \mathrm{g}=0.035 \mathrm{oz}$

"Harvested on 4 Sept.

"Harvested on 16 Sept. in the first year and 18 Sept. in the second and third years.

${ }^{t}$ Means in a column, not followed by a common letter are significantly different by analysis of variance $(P \geq 0.05)$.

split, split plot treatment arrangement with splits for year, location, and harvest and completely randomized design for storage by the SAS General Linear Models (GLM) procedure, where the type III comparison-wise error rate was controlled (SAS 1999). Data are reported as least square means (LS means) with Tukey's HSD mean separation.

\section{Results and discussion}

FLESH FIRMNESS, SSC, TA, FRUIT COLOR, AND FRUIT WEIGHT AT HARVEST. A 2 -week delay in harvest resulted in some change in maturity indices (Table 1). Firmness did not change as harvest was delayed, but SSC increased and TA decreased. There was a reduction of $<3.0$ $\mathrm{N}(0.67 \mathrm{lbf})$ in firmness over the 2 weeks between harvest I and II, but this loss in firmness was not significant. Changes in firmness are generally considered one of the most reliable indicators of pear maturity, and a change in firmness of this magnitude would be considered important (Chen and Mellenthin, 1981; Tvergyak 1985). An increase in the SSC:TA ratio from 8.2 to 10.3 , as harvest was delayed, could enhance consumer appeal. Consumer preference for fruit is reported to improve with increased SSC:TA ratios (Boylson et al., 1994).

Delay of harvest resulted in a change in peel color only for the color parameter $\mathrm{a}^{*}$. This change in $\mathrm{a}^{*}$ would indicated a less green fruit for the later harvested pears. It is doubtful that this change in color $\left(\mathrm{a}^{*}\right)$ would be of commercial importance as color differences must be one unit or greater to be visible to the human eye (Hunter and Harold, 1987). There was no change in $L^{*}, b^{*}$, or calculated hue values, demonstrating no visible peel color difference between harvests. There was a significant increase in pear weight of $24.0 \mathrm{~g}(0.85 \mathrm{oz})$ as harvest was delayed. This change in weight would equal an increase in one box size and would suggest that a delay in harvest could be of economic advantage to the grower.

FLESH FIRMNESS, SSC, AND TA IN RA STORAGE. 'Concorde' pears maintained good quality in regular atmosphere storage for $90 \mathrm{~d}$ regardless of harvest date; quality was reduced after $90 \mathrm{~d}$ or more of RA storage (Table 2). A significant harvest by storage interaction occurred in flesh firmness. Harvest date had no effect on firmness during the first 90 d of storage. After $90 \mathrm{~d}$ of storage, pears from either harvest date showed dramatic losses in firmness. After 150 $\mathrm{d}$ of storage, pears from harvest I lost more firmness than pears from harvest

Table 2. Quality attributes for 'Concorde' pears harvested at two levels of maturity, after 45, 90, or 150 d in regular atmosphere storage and evaluated after 0 and $7 \mathrm{~d}$ of ripening.

\begin{tabular}{|c|c|c|c|c|c|c|c|c|}
\hline \multirow{3}{*}{$\begin{array}{l}\text { Maturity } \\
\text { level }\end{array}$} & \multirow{3}{*}{$\begin{array}{l}\text { Firmness }^{\mathrm{z}} \\
(\mathrm{N})\end{array}$} & \multirow{3}{*}{$\begin{array}{c}\mathrm{SSC}^{\mathrm{y}} \\
(\%)\end{array}$} & \multirow{3}{*}{$\begin{array}{l}\mathrm{TA}^{\mathrm{x}} \\
(\%)\end{array}$} & \multirow{3}{*}{$\begin{array}{c}\text { SSC:TA } \\
\text { (ratio) }\end{array}$} & \multicolumn{4}{|c|}{ Color } \\
\hline & & & & & \multicolumn{2}{|c|}{ Peel } & \multicolumn{2}{|c|}{ Flesh } \\
\hline & & & & & $\mathrm{L}^{*}$ & Hue & $\mathrm{L}^{*}$ & Hue \\
\hline \multicolumn{9}{|l|}{ Harvest } \\
\hline$I^{\mathrm{w}}$ & 28.4 & $15.7 b^{u}$ & 0.15 & 11.2 & $61.0 \mathrm{a}$ & 89.9 a & $72.6 \mathrm{a}$ & $87.0 \mathrm{a}$ \\
\hline $\mathrm{II}^{\mathrm{v}}$ & 29.0 & $16.3 \mathrm{a}$ & 0.12 & 14.7 & $61.2 \mathrm{a}$ & 89.8 a & $72.3 \mathrm{a}$ & $86.7 \mathrm{a}$ \\
\hline \multicolumn{9}{|l|}{ Storage (d) } \\
\hline 45 & 32.2 & $16.2 \mathrm{a}$ & 0.16 & 11.1 & $57.1 \mathrm{~b}$ & $98.6 \mathrm{a}$ & $71.1 \mathrm{~b}$ & $89.4 \mathrm{a}$ \\
\hline \multicolumn{9}{|l|}{ Ripe (d) } \\
\hline 0 & $44.8 \mathrm{a}$ & $16.0 \mathrm{a}$ & $0.13 \mathrm{a}$ & $13.1 \mathrm{a}$ & $58.8 \mathrm{~b}$ & $94.9 \mathrm{a}$ & $72.2 \mathrm{a}$ & $87.8 \mathrm{a}$ \\
\hline 7 & $12.6 \mathrm{~b}$ & $16.1 \mathrm{a}$ & $0.14 \mathrm{a}$ & $12.8 \mathrm{~b}$ & $63.4 \mathrm{a}$ & $84.8 \mathrm{~b}$ & $72.7 \mathrm{a}$ & $86.0 \mathrm{~b}$ \\
\hline Harvest $\times$ storage & ** & NS & ** & ** & NS & NS & NS & NS \\
\hline \multicolumn{9}{|l|}{ I } \\
\hline 45 & $32.8 \mathrm{a}$ & & $0.17 \mathrm{a}$ & $10.1 \mathrm{de}$ & & & & \\
\hline 90 & $30.0 \mathrm{a}$ & & $0.10 \mathrm{c}$ & $17.1 \mathrm{a}$ & & & & \\
\hline 150 & $25.1 \mathrm{~b}$ & & $0.11 \mathrm{c}$ & $14.8 \mathrm{~b}$ & & & & \\
\hline
\end{tabular}

${ }^{2} 1.0 \mathrm{~N}=0.225 \mathrm{lbf}$.

ySC $=$ soluble solids concentration.

${ }^{x} \mathrm{TA}=$ titratable acidity expressed as percent malic acid

"Harvested on 4 Sept.

"Harvested on 16 Sept. in the first year and 18 Sept. in the second and third years.

"Means in a column, within treatments, not followed by a common letter are significantly different $(P \geq 0.05)$ by Tukey's honestly significant difference test. 
II [21.7 vs. $25.1 \mathrm{~N}$ (4.88 vs. $5.64 \mathrm{lbf})$ ], but pears with firmness values this low are not good candidates for handling or shipping (Chen and Mellenthin, 1981).

A harvest delay of $10 \mathrm{~d}$ increased the SSC of 'Concorde' pears (Table 2). Increasing the length of RA storage by more than $90 \mathrm{~d}$ resulted in decrease in SSC. There was no significant interaction in storage or harvest conditions with respect to SSC. Ripening did not affect SSC.

Along with increasing SSC, changes in TA and SSC:TA ratios were also observed. Significant harvest by storage interactions occurred for both TA and SSC:TA ratios. TA levels following $45 \mathrm{~d}$ of storage were similar for both harvest dates (Table 2). TA levels in fruit from harvest I were not reduced until after $90 \mathrm{~d}$ of RA storage, while TA levels in fruit from harvest II were significantly reduced by $90 \mathrm{~d}$ of RA storage. By 150 $\mathrm{d}$ of RA storage, TA levels were similar. SSC:TA ratios were lower following 45 $\mathrm{d}$ of RA storage in fruits from harvest I as compared to harvest II. SSC:TA ratios were similar for harvest I fruit stored under RA conditions for either 45 or $90 \mathrm{~d}$, but increased in fruit stored for $150 \mathrm{~d}$. SSC:TA ratios in fruit from harvest II were higher following 90 $\mathrm{d}$ of RA storage as compared to 45 d RA storage. By 150 d RA storage, the SSC:TA ratio in fruit from harvest II had decreased as compared to that after 90 d storage; however, the SSC: TA ratios were still higher after $150 \mathrm{~d}$ RA storage compared to those after 45 d RA storage.

Fruit COlor in RA storage. L* color values for the peel or flesh of 'Concorde' pears were not influenced by harvest date, but peel $\mathrm{L}^{*}$ values did increase due to time in storage and ripening (Table 2). Between 45 and $90 \mathrm{~d}$ of RA storage there was a increase in $L^{*}$ values by more than 5 color units. No further increase in $\mathrm{L}^{*}$ peel values was evident as RA storage time increased from 90 to $150 \mathrm{~d}$. This increase in $\mathrm{L}^{*}$ peel values was also evident during ripening, where $L^{*}$ values increased by nearly 5 units. Storage time influenced the $L^{*}$ color values for the flesh of 'Concorde' pears. Flesh $L^{*}$ values were higher following $90 \mathrm{~d}$ RA storage as compared to either 45 or $150 \mathrm{~d}$ RA Storage. Flesh $L^{*}$ values were not affected by ripening.

Harvest time had no influence on the hue of the peel or flesh of 'Con- corde' pears. However, time in storage and ripening reduced the hue of both the peel and the flesh. This reduction in hue indicates a more yellow, or less green, color pear as storage time progressed and during $7 \mathrm{~d}$ of ripening. These changes ( $>1.0$ units) in hue, for both storage time and ripening would be visible to the human eye (Hunter and Harold, 1987).

FruIt APPEARANCE, PEDICEL CONDITION, AND INTERNAL BREAKDOWN IN RA STORAGE. Subjective evaluations of the appearance and pedicel condition of 'Concorde' pears were strongly influ- enced by the interaction of harvest and storage time (Table 3 ). After 45 d of RA storage fruit appearance was similar regardless of harvest time (Table 3). After $90 \mathrm{~d}$ RA storage the appearance values for pears from harvest I were superior to the appearance values of pears picked at harvest II. Appearance values continued to decline as RA storage progressed from 90 to $150 \mathrm{~d}$. The decline in fruit appearance was greater for fruit from harvest I as compared to fruit from harvest II. 'Concorde' fruit from harvest II had unacceptable appearance values $(>2.0)$ after $150 \mathrm{~d}$ RA storage, whereas the

Table 3. Subjective evaluation of 'Concorde' pears after regular atmosphere storage of 45,90 , or $150 \mathrm{~d}$.

\begin{tabular}{|c|c|c|c|}
\hline Factor & $\begin{array}{c}\text { Appearance } \\
(1 \text { to } 4)^{z}\end{array}$ & $\begin{array}{l}\text { Pedicel } \\
(1 \text { to } 4)^{\mathrm{z}}\end{array}$ & $\begin{array}{c}\text { Internal } \\
\text { breakdown (\%) }\end{array}$ \\
\hline \multicolumn{4}{|l|}{ Harvest } \\
\hline $\mathrm{I}^{\mathrm{y}}$ & 1.4 & 2.3 & $3.9 \mathrm{a}^{\mathrm{w}}$ \\
\hline $\mathrm{II}^{\mathrm{x}}$ & 1.7 & 2.5 & $8.3 \mathrm{a}$ \\
\hline \multicolumn{4}{|l|}{ Storage $(\mathrm{d})$} \\
\hline $45^{\circ}$ & 1.0 & 1.6 & $0.4 \mathrm{~b}$ \\
\hline 90 & 1.5 & 2.4 & $1.7 \mathrm{~b}$ \\
\hline 150 & 2.1 & 3.3 & $16.3 \mathrm{a}$ \\
\hline \multicolumn{4}{|l|}{ Ripe (d) } \\
\hline 0 & $1.4 \mathrm{~b}$ & $2.0 \mathrm{~b}$ & $2.8 \mathrm{~b}$ \\
\hline 7 & $1.7 \mathrm{a}$ & $2.9 \mathrm{a}$ & $9.4 \mathrm{a}$ \\
\hline Harvest $\times$ storage & $* *$ & $* *$ & NS \\
\hline I 45 & $1.0 \mathrm{~d}$ & $1.7 \mathrm{~d}$ & \\
\hline 90 & $1.4 \mathrm{c}$ & $2.3 \mathrm{c}$ & \\
\hline 150 & $1.8 \mathrm{~b}$ & $3.0 \mathrm{~b}$ & \\
\hline II 45 & $1.1 \mathrm{~d}$ & $1.6 \mathrm{~d}$ & \\
\hline 90 & $1.7 \mathrm{~b}$ & $2.5 \mathrm{c}$ & \\
\hline 150 & $2.5 \mathrm{a}$ & $3.5 \mathrm{a}$ & \\
\hline
\end{tabular}

${ }^{2}$ Evaluated on a scale of 1 to 4 ( 1 = excellent, $2=\operatorname{good}, 3$ = fair, $4=$ poor $)$.

Harvested on 4 Sept.

${ }^{x}$ Harvested on 16 Sept. in the first year and 18 Sept. in the second year.

"Means in a column, within treatments, not followed by a common letter are significantly different $(P \geq 0.05)$ by Tukey's honestly significant difference test.

Table 4. Peel color and internal breakdown of 'Concorde' pears harvested at two levels of maturity, stored under two controlled atmosphere storage conditions [1.5\% oxygen $\left(\mathrm{O}_{2}\right)+1.0 \%$ carbon dioxide $\left(\mathrm{CO}_{2}\right)$ and $\left.1.5 \% \mathrm{O}_{2}+3.0 \% \mathrm{CO}_{2}\right)$, for 90 or $180 \mathrm{~d}$ and evaluated after 0 and $7 \mathrm{~d}$ of ripening.

\begin{tabular}{|c|c|c|c|c|}
\hline \multirow[b]{2}{*}{ Factor } & \multicolumn{3}{|c|}{ Peel color } & \multirow{2}{*}{$\begin{array}{c}\text { Internal } \\
\text { breakdown } \\
(\%)\end{array}$} \\
\hline & $\mathrm{L}^{*}$ & $a^{*}$ & Hue & \\
\hline \multicolumn{5}{|l|}{$\begin{array}{l}\text { Harvest } \times \text { atmosphere } \\
\mathrm{I}^{\mathrm{z}}\end{array}$} \\
\hline $\begin{array}{r}1.5 \% \mathrm{O}_{2}+1.0 \% \mathrm{CO}_{2} \\
1.5 \% \mathrm{O}_{2}+3.0 \% \mathrm{CO}_{2}\end{array}$ & $\begin{array}{l}58.7 b^{x} \\
57.7 c^{-}\end{array}$ & $\begin{array}{l}-2.3 b c \\
-2.7 c\end{array}$ & $\begin{array}{l}94.6 \mathrm{~b} \\
96.1 \mathrm{a}\end{array}$ & $\begin{array}{l}6.7 \mathrm{bc} \\
2.9 \mathrm{c}\end{array}$ \\
\hline $\begin{array}{r}1.5 \% \mathrm{O}_{2}+1.0 \% \mathrm{CO}_{2} \\
1.5 \% \mathrm{O}_{2}+3.0 \% \mathrm{CO}_{2} \\
\text { Storage }(\mathrm{d}) \times \text { ripe }(\mathrm{d})\end{array}$ & $\begin{array}{l}60.5 \mathrm{a} \\
58.7 \mathrm{~b}\end{array}$ & $\begin{array}{l}-0.3 \mathrm{a} \\
-2.2 \mathrm{~b}\end{array}$ & $\begin{array}{l}90.0 \mathrm{c} \\
94.8 \mathrm{~b}\end{array}$ & $\begin{array}{r}9.2 \mathrm{~b} \\
18.8 \mathrm{a}\end{array}$ \\
\hline $\begin{array}{l}90 \\
7 \\
180 \\
7\end{array}$ & $\begin{array}{l}54.7 \mathrm{c} \\
60.9 \mathrm{a} \\
59.0 \mathrm{~b} \\
61.0 \mathrm{a}\end{array}$ & $\begin{array}{r}-6.1 \mathrm{~d} \\
-0.5 \mathrm{~b} \\
-2.1 \mathrm{c} \\
1.2 \mathrm{a}\end{array}$ & $\begin{array}{r}103.5 \mathrm{a} \\
90.8 \mathrm{c} \\
94.2 \mathrm{~b} \\
87.9 \mathrm{~d}\end{array}$ & $\begin{array}{r}7.1 \mathrm{~b} \\
7.5 \mathrm{~b} \\
10.2 \mathrm{a} \\
12.7 \mathrm{a}\end{array}$ \\
\hline
\end{tabular}

${ }^{2}$ Harvested on 4 Sept.

yHarvested on 16 Sept. in the first year and 18 Sept. in the second year.

${ }^{x}$ Means in a column, within treatments, not followed by a common letter are significantly different $(P \geq 0.05)$ by Tukey's honestly significant difference test. 
Table 5. Quality attributes of 'Concorde' pears harvested at two levels of maturity, stored under two controlled atmosphere storage conditions $\left[1.5 \%\right.$ oxygen $\left(\mathrm{O}_{2}\right)+1.0 \%$ carbon dioxide $\left(\mathrm{CO}_{2}\right)$, and $\left.1.5 \% \mathrm{O}_{2}+3.0 \% \mathrm{CO}_{2}\right]$ for 90 or $180 \mathrm{~d}$ and evaluated after 0 and $7 \mathrm{~d}$ of ripening.

\begin{tabular}{|c|c|c|c|c|c|}
\hline Treatment & $\begin{array}{l}\text { Firmness }^{z} \\
(\mathrm{~N})\end{array}$ & $\begin{array}{l}\mathrm{SSC}^{\mathrm{y}} \\
(\%)\end{array}$ & $\begin{array}{l}\text { TA }^{x} \\
(\%)\end{array}$ & $\begin{array}{c}\text { SSC:TA } \\
\text { (ratio) }\end{array}$ & $\begin{array}{l}\text { Pedicel } \\
(1 \text { to } 4)^{\mathrm{w}}\end{array}$ \\
\hline \multicolumn{6}{|l|}{ Harvest } \\
\hline $\mathrm{I}^{\mathrm{u}}$ & $29.7 \mathrm{a}^{\mathrm{t}}$ & $15.7 \mathrm{~b}$ & $0.16 \mathrm{a}$ & $10.1 \mathrm{~b}$ & $2.1 \mathrm{a}$ \\
\hline $\mathrm{II}^{\mathrm{v}}$ & $29.3 \mathrm{a}$ & $16.3 \mathrm{a}$ & $0.13 \mathrm{~b}$ & $13.2 \mathrm{a}$ & $2.2 \mathrm{a}$ \\
\hline \multicolumn{6}{|l|}{ Atmosphere } \\
\hline $1.5 \% \mathrm{O}_{2}+1.0 \% \mathrm{CO}_{2}$ & $29.0 \mathrm{a}$ & $16.0 \mathrm{a}$ & $0.15 \mathrm{a}$ & $11.6 \mathrm{a}$ & $2.2 \mathrm{a}$ \\
\hline $\begin{array}{c}1.5 \% \mathrm{O}_{2}^{2} \\
\text { St }\end{array}$ & $30.0 \mathrm{a}$ & $16.0 \mathrm{a}$ & $0.14 \mathrm{a}$ & $11.6 \mathrm{a}$ & $2.1 \mathrm{a}$ \\
\hline \multicolumn{6}{|l|}{ Storage $\times$ ripening } \\
\hline $\begin{array}{ll}90 & 0 \\
& 7\end{array}$ & $50.2 \mathrm{a}$ & $16.1 \mathrm{a}$ & $0.14 \mathrm{ab}$ & $12.2 \mathrm{a}$ & $1.9 \mathrm{c}$ \\
\hline 7 & $12.8 \mathrm{c}$ & $16.5 \mathrm{a}$ & $0.16 \mathrm{a}$ & $11.2 \mathrm{~b}$ & $2.1 \mathrm{~b}$ \\
\hline \multirow{2}{*}{$\begin{array}{ll}180 & 0 \\
& 7\end{array}$} & $40.1 \mathrm{~b}$ & $16.0 \mathrm{a}$ & $0.15 \mathrm{ab}$ & $11.3 \mathrm{~b}$ & $2.4 \mathrm{a}$ \\
\hline & $14.9 \mathrm{c}$ & $15.3 \mathrm{~b}$ & $0.13 \mathrm{~b}$ & $11.8 \mathrm{ab}$ & $2.4 \mathrm{a}$ \\
\hline
\end{tabular}

${ }^{2} 1.0 \mathrm{~N}=0.225 \mathrm{lbf}$.

ySC $=$ soluble solids concentration

${ }^{\mathrm{T} A}=$ titratable acidity expressed as percent malic acid

"Evaluated on a scale of 1 to $4(1=$ excellent, $2=$ good, $3=$ fair, $4=$ poor $)$.

"Harvested on 4 Sept.

"Harvested on 16 Sept. in the first year and 18 Sept. in the second year.

'Means in a column, within treatments, not followed by a common letter are significantly different $(P \geq 0.05)$ by Tukey's honestly significant difference test.

appearance values for fruit from harvest I were still acceptable $(<2.0)$ following $150 \mathrm{~d}$ RA storage. Ripening for $7 \mathrm{~d}$ reduced fruit appearance.

Pedicel condition significantly declined between 45 and $90 \mathrm{~d}$ RA storage among both harvest I and harvest II fruit (Table 3); however, pedicel condition was not different between harvest I and harvest II. Pedicel condition deteriorated between 90 and $150 \mathrm{~d}$ RA storage. Pedicel condition of harvest II was poorer than harvest I fruit; however, the pedicel condition of both were unacceptable (>2.0). Ripening fruit for $7 \mathrm{~d}$ resulted in pedicel condition changing, from marginally acceptable (2.0) to very unacceptable (2.9).

Internal breakdown was not influenced by harvest time, but was highly influenced by storage time and ripening. Little or no internal breakdown was evident after 45 and $90 \mathrm{~d}$ of storage, but after $150 \mathrm{~d}$ of RA storage internal breakdown increased. Ripening for 7 $\mathrm{d}$ increased internal breakdown about 3 -fold.

FRUIT COLOR AND INTERNAL BREAKDOWN IN CA Storage. Peel color $\left(\mathrm{L}^{*}\right.$ and hue) and internal breakdown were influenced by the interaction of harvest and CA storage atmosphere (Table 4). Pears from harvest II stored in a CA of $1.5 \% \mathrm{O}_{2}+1.0 \% \mathrm{CO}_{2}$ displayed the highest $\mathrm{L}^{*}$ values, indicating a lighter color when compared to pears from harvest I or pears from harvest II stored in a CA of $1.5 \% \mathrm{O}_{2}+3.0 \% \mathrm{CO}_{2}$. Regardless of harvest, pears stored in a CA of $1.5 \%$ $\mathrm{O}_{2}+3.0 \% \mathrm{CO}_{2}$ displayed the lowest $\mathrm{L}^{*}$ values, indicating a darker color than pears stored in a CA of $1.5 \% \mathrm{O}_{2}+1.0 \%$ $\mathrm{CO}_{2}$. Pears from harvest II stored in a $\mathrm{CA}$ of $1.5 \% \mathrm{O}_{2}+1.0 \% \mathrm{CO}_{2}$ were more yellow (lower hue values) than pears from harvest I regardless of storage atmosphere. Pears from harvest I stored in a $\mathrm{CA}$ of $1.5 \% \mathrm{O}_{2}+3.0 \% \mathrm{CO}_{2}$ were greener (higher hue values) than pears from harvest II or pears from harvest I stored in a CA of $1.5 \% \mathrm{O}_{2}+1.0 \% \mathrm{CO}_{2}$. Hue values for pears from harvest II in a $\mathrm{CA}$ of $1.5 \% \mathrm{O}_{2}+3.0 \% \mathrm{CO}_{2}$ were comparable to pears from harvest $\mathrm{I}$ in a CA of $1.5 \% \mathrm{O}_{2}+1.0 \% \mathrm{CO}_{2}$.

Time in CA storage and ripening

also had a significant, interactive influence on peel color (Table 4). Pears stored for $90 \mathrm{~d}$ with no ripening had lower peel $\mathrm{L}^{*}$ values than pears stored for $180 \mathrm{~d}$ with no ripening, indicating a darker colored fruit. After ripening, peel $\mathrm{L}^{*}$ values were identical, regardless of storage. Pears examined immediately afterstorage for $90 \mathrm{~d}$ were greener (higher hue values) than pears immediately after storage for $180 \mathrm{~d}$. After ripening, pears stored for $90 \mathrm{~d}$ were greener than pears stored for $180 \mathrm{~d}$. These color changes in peel $\mathrm{L}^{*}$ and hue would be visible in that all are in excess of 1.0 color units.

Table 6. Analysis of variance of the effect of year, location, harvest, and storage conditions on fruit astringency, flavor, and texture of 'Concorde' pears.

\begin{tabular}{|c|c|c|c|c|}
\hline Source & df & Astringency ${ }^{z}$ & Flavor $^{y}$ & Texture \\
\hline Year (Y) & 2 & NS & NS & NS \\
\hline Error A & 15 & --- & --- & --- \\
\hline Location (L) & 2 & NS & NS & NS \\
\hline $\mathrm{Y} \times \mathrm{L}$ & 4 & NS & NS & NS \\
\hline Error B & 30 & --- & --- & --- \\
\hline Harvest $(\mathrm{H})$ & 2 & $* * *$ & $* * *$ & $* * *$ \\
\hline $\mathrm{Y} \times \mathrm{H}$ & 4 & NS & NS & NS \\
\hline $\mathrm{L} \times \mathrm{H}$ & 4 & NS & NS & NS \\
\hline $\mathrm{Y} \times \mathrm{L} \times \mathrm{H}$ & 4 & NS & NS & NS \\
\hline Error C & 90 & -- & --- & --- \\
\hline Storage $(S)$ & 3 & $* * *$ & $* * *$ & $* * *$ \\
\hline $\mathrm{Y} \times \mathrm{S}$ & 6 & NS & NS & NS \\
\hline $\mathrm{L} \times \mathrm{S}$ & 6 & NS & NS & NS \\
\hline $\mathrm{H} \times \mathrm{S}$ & 6 & $* * *$ & NS & $* * *$ \\
\hline $\mathrm{Y} \times \mathrm{L} \times \mathrm{S}$ & 12 & NS & NS & NS \\
\hline $\mathrm{Y} \times \mathrm{H} \times \mathrm{S}$ & 12 & NS & NS & NS \\
\hline $\mathrm{L} \times \mathrm{H} \times \mathrm{S}$ & 12 & NS & NS & NS \\
\hline $\mathrm{Y} \times \mathrm{L} \times \mathrm{H} \times \mathrm{S}$ & 24 & NS & NS & NS \\
\hline Error D & 405 & --- & --- & --- \\
\hline
\end{tabular}

${ }^{\mathrm{z}} 10$-Point scale, where $0=$ none, $9=$ very severe.

y 10 -Point scale, where $0=$ least, $9=$ highest.

${ }^{x} 10$-Point scale, where $0=$ poorest, 9 = best.

Ns, $,{ }^{* *},{ }^{* * *}$ Nonsignificant or significant at $P \geq 0.05,0.01$, or 0.001 , respectively. 
Internal breakdown of pears from harvest I was not influenced by storage atmosphere, but the internal breakdown of pears from harvest II was strongly influenced by storage atmosphere (Table 4). Pears from harvest II in a CA of $1.5 \% \mathrm{O}_{2}+3.0 \% \mathrm{CO}_{2}$ displayed excessive (18.8\%) internal breakdown. Pears from harvest II in a CA of $1.5 \%$ $\mathrm{O}_{2}+1.0 \% \mathrm{CO}_{2}$ displayed no more internal breakdown than pears from harvest $\mathrm{I}$ in a CA of $1.5 \% \mathrm{O}_{2}+1.0 \%$ $\mathrm{CO}_{2}$. Ripening time had no influence on the amount of internal breakdown present, only length of CA storage. 'Concorde' pears stored for $90 \mathrm{~d}$ in CA displayed less internal breakdown than pears stored for $180 \mathrm{~d}$.

Flesh firmness, SSC, TA and PediCEL CONDITION IN CA StORAge. Harvest time and CA conditions had no influence on the flesh firmness of 'Concorde' pears. There was a significant storage by ripening interaction for fruit stored under CAconditions (Table 5). Fruit stored for $180 \mathrm{~d}$ under CA conditions had lower flesh firmness, compared to fruit stored in CA for $90 \mathrm{~d}$ immediately following storage (Table 5 ). However, after $7 \mathrm{~d}$ of ripening fruit from both storage lengths had similar flesh firmness values.

SSC levels in fruit from harvest I were lower following CA storage than for fruit from harvest II (Table 5). CA storage conditions did not affect SSC levels. A significant storage by ripening interaction was observed for SSC levels. SSC levels in unripened fruit were not affected by the length of storage; however, ripened fruit had a lower SSC level following $180 \mathrm{~d}$ of CA storage as compared to fruit with $90 \mathrm{~d}$ CA storage. TA levels in fruit from harvest I were higher following CA storage than those of fruit from harvest II (Table 5). CA storage conditions did not affect TA levels. A storage by ripening interaction was observed for TA levels. TA levels in unripened fruit were not affected by the length of CA storage. Ripened fruit had lower TA levels following $180 \mathrm{~d}$ CA storage as compared to $90 \mathrm{~d}$ CA storage. Fruit from harvest II had higher SSC:TA ratios than did fruit from harvest I following CA storage. CA storage conditions did not affect SSC:TA ratios. Ripening lowered the SSC:TA ratio following $90 \mathrm{~d}$ CA storage, but had no effect of SSC:TA ratios following $180 \mathrm{~d}$ CA storage.

Pedicel condition of 'Concorde' pears following CA storage was not affected by harvest timing or CA stor- age conditions (Table 5). The pedicel condition for pears stored under CA conditions for $90 \mathrm{~d}$ with no ripening was still acceptable (1.9), whereas pears stored for $90 \mathrm{~d}$ and ripened had a pedicel condition that was barely unacceptable (2.1). The pedicel condition of pears stored for $180 \mathrm{~d}$ under CA conditions was unacceptable (2.4) before or after ripening.

\section{FRUIT ASTRINGENCY, FLAVOR, AND TEX-}

Table 7. Effect of year, location, harvest, and storage conditions on fruit astringency, flavor, and texture of 'Concorde' pears. Data are least squares means.

\begin{tabular}{cccc}
\hline Factor & $\begin{array}{c}\text { Astringency } \\
(\mathbf{0}-\mathbf{9})^{\mathrm{y}}\end{array}$ & $\begin{array}{c}\text { Flavor } \\
(\mathbf{0}-\mathbf{9})^{\mathrm{y}}\end{array}$ & $\begin{array}{c}\text { Texture } \\
(\mathbf{0}-\mathbf{9})^{\mathrm{x}}\end{array}$ \\
\hline Year & & & \\
1999 & 0.47 & 6.62 & 6.52 \\
2000 & 0.46 & $6.1 \mathrm{l}$ & 6.68 \\
2001 & 0.48 & 6.56 & 6.67 \\
Location $^{\mathrm{w}}$ & & & 6.63 \\
WA-1 & 0.48 & 6.64 & 6.69 \\
OR-1 & 0.47 & 6.58 & 6.67 \\
OR-2 & 0.46 & 6.57 & $6.92 \mathrm{a}$ \\
Harvest & & & $7.03 \mathrm{a}$ \\
1 & $1.29 \mathrm{a}^{\mathrm{u}}$ & $7.94 \mathrm{a}$ & $6.05 \mathrm{~b}$ \\
2 & $0.12 \mathrm{~b}$ & $5.85 \mathrm{~b}$ & $7.25 \mathrm{a}$ \\
3 & $0.00 \mathrm{c}$ & & $7.87 \mathrm{~b}$ \\
Storage & & $7.83 \mathrm{a}$ & $6.25 \mathrm{c}$ \\
RA-1 & $0.00 \mathrm{c}$ & $7.81 \mathrm{a}$ & $5.29 \mathrm{~d}$ \\
RA-2 & $0.00 \mathrm{c}$ & $5.86 \mathrm{~b}$ & \\
RA-4 & $0.25 \mathrm{~b}$ & $4.89 \mathrm{c}$ & \\
CA-4 & $1.63 \mathrm{c}$ & & \\
\hline
\end{tabular}

${ }^{2} 10$-Point scale, where $0=$ none, $9=$ very severe.

y 0 -Point scale, where $0=$ least, $9=$ highest.

× 10 -Point scale, where $0=$ poorest, $9=$ best.

"WA- 1 = fruit grown in Washington, OR-1 and OR-2 = fruit grown in Oregon on Bartlett Seedling or Old Home x Farmingdale rootstock, respectively.

${ }^{\mathrm{x}} \mathrm{l}=$ harvest on 4 Sept., 2 = harvest on 18 Sept., $3=$ harvest on 2 Oct.

"Means within a column, within factors not followed by a common letter are significantly different at $P \geq 0.05$.

'RA-1, 2, and $4=$ regular atmosphere storage for 30,60 and $120 \mathrm{~d}$, respectively; CA- $4=$ controlled atmosphere storage for $120 \mathrm{~d}$.

Table 8. Interaction between harvest and storage conditions on fruit astringency and texture of 'Concorde' pears. Data are least squares means.

\begin{tabular}{|c|c|c|}
\hline Factor $^{\mathrm{x}}$ & $\begin{array}{c}\text { Astringency } \\
(0-9)\end{array}$ & $\begin{array}{c}\text { Texture }^{y} \\
(0-9)\end{array}$ \\
\hline \multicolumn{3}{|c|}{ Harvest 1 (4 Sept.) } \\
\hline RA-1 & $0.00 \mathrm{~d}^{\mathrm{w}}$ & $6.68 \mathrm{e}$ \\
\hline RA-2 & $0.00 \mathrm{~d}$ & $7.57 \mathrm{c}$ \\
\hline RA-4 & $0.74 \mathrm{~b}$ & $7.18 \mathrm{~d}$ \\
\hline CA-4 & $4.25 \mathrm{a}$ & $6.24 \mathrm{f}$ \\
\hline \multicolumn{3}{|c|}{ Harvest 2 (18 Sept.) } \\
\hline RA-1 & $0.00 \mathrm{~d}$ & $7.94 \mathrm{~b}$ \\
\hline RA-2 & $0.00 \mathrm{~d}$ & $8.35 \mathrm{a}$ \\
\hline RA-4 & $0.00 \mathrm{~d}$ & $6.00 \mathrm{fg}$ \\
\hline $\mathrm{CA}-4$ & $0.46 \mathrm{c}$ & $5.81 \mathrm{gh}$ \\
\hline \multicolumn{3}{|c|}{ Harvest 3 (2 Oct.) } \\
\hline RA-1 & $0.00 \mathrm{~d}$ & $7.13 \mathrm{~d}$ \\
\hline RA-2 & $0.00 \mathrm{~d}$ & $7.68 \mathrm{bc}$ \\
\hline RA-4 & $0.00 \mathrm{~d}$ & $5.57 \mathrm{~h}$ \\
\hline CA-4 & $0.00 \mathrm{~d}$ & $3.81 \mathrm{I}$ \\
\hline
\end{tabular}


a $\mathrm{CO}_{2}$ level in storage. The initial two harvest dates (onset of commercial CA 'd'Anjou' harvest and $14 \mathrm{~d}$ later) did not affect flavor; however, extending the harvest period an additional $14 \mathrm{~d}$ did lower fruit flavor. The first two harvest dates approximately coincided with harvests I and II reported in Tables I through 5 . The primary reason for the reduction of fruit flavor was a shifting of an overall sensation of sweetness to one of an overpowering sweet, syrupy taste with little acid to balance flavor. This shift in flavor was more noticeable after 4 months storage. The observed change in flavor with the delayed harvest was supported by the increase in soluble solids shown in Tables 1 and 2 between the two harvests and the trend to decreasing TA levels and increasing SSC:TA ratios with the later harvest period or length of storage.

Significant harvest by storage interactions affecting astringency and fruit texture were observed (Table 6). Fruit astringency increased between 2 and 4 months of RA storage in the fruit harvested at the first harvest period (Table 8). The increase in astringency was more dramatic in the samples stored under low oxygen CA for 4 months. This may have been caused by the low oxygen CA conditions themselves, or by the excessive storage duration, or both. Significant astringency was only detected in fruit from the second harvest period following the 4 months CA storage, and astringency was not detected in fruit from the third harvest period. This suggests that as the fruit matures on the tree it loses the ability to produce astringent compounds during storage. It is also possible that increased SSC could be masking the astringency.

Ripened fruit texture was also affected by harvest period by storage period interactions (Table 6). Fruit from the first harvest period reached its best texture following 2 months RA storage (Table 8 ). Fruit stored for only 1 month was drier and did not develop the smooth, buttery texture of the fruit stored for 2 months. This increase in the smooth, buttery texture was also noted between the 1- and 2-month storage samples of the fruit from the second and third harvest dates. This suggests that 'Concorde' pears need more than
1 month of cold storage after harvest to develop the best texture. Fruit from both the second and third harvest dates exhibited significantly better texture following 1 month of storage than fruit from the first harvest date. By the time the fruit had been stored for 4 months under RA or CA conditions, fruit texture significantly declined. This was due mainly to the development of a dry, mealy texture following the 7-d ripening period. Fruit evaluated after 5 $\mathrm{d}$ of ripening were less mealy, but did not develop a smooth, buttery texture (data not shown). These data indicate that for longer-term storage it would be better from a textural standpoint to harvest the fruit earlier; however, the early-harvested fruit had reduced flavor and increased astringency following longer-term storage.

\section{Conclusions}

'Concorde' pears can be harvested over a 10 -d period beginning at 57.0 $\mathrm{N}$ firmness with no loss in quality and be stored successfully in either RA or CA storage. A 10-d delay in harvest resulted in no change in firmness or color and enhanced SSC and fruit size. Regardless of harvest time, 'Concorde' pears could be stored in RA storage for periods up to $90 \mathrm{~d}$, beyond which reduced appearance, pedicel conditions and enhanced internal breakdown occurred. Early harvest should be considered when RA storage is expected to exceed $90 \mathrm{~d}$; however, the danger of the fruit developing astringency does exist. Regardless of harvest, 'Concorde' pears could be stored in CA for up to $180 \mathrm{~d}$ with no serious quality losses, particularly if the $\mathrm{CA}$ was maintained at $1.5 \% \mathrm{O}_{2}+1.0 \% \mathrm{CO}_{2}$. Internal breakdown of' 'Concorde' pears was a serious problem in CA if the $\mathrm{CO}_{2}$ exceeds $1.0 \%$. Low oxygen $\mathrm{CA}\left(1.0 \% \mathrm{O}_{2}\right.$ and $<0.1 \% \mathrm{CO}_{2}$ ) cannot be recommended for 'Concorde' pears.

\section{Literature cited}

Boylson, T.D., E.M. Kupferman, J.D. Foss, and C. Buering. 1994. Sensory quality of 'Gala' apples as influenced by controlled and regular atmosphere storage. J. Food Qual. $17: 477-494$

Chen, P.M. and W.M. Mellenthin. 1981. Effects of harvest date on ripening capacity and postharvest life of 'd'Anjou' pears. J. Amer. Soc. Hort. Sci. 106:38-42.

Chen, P.M., D.M. Varga, and T.J. Facteau. 1994. Ripening behavior of 'Gebhard' strain of red 'd'Anjou' pears after cold storage as influenced by harvest maturity and ethylene. Acta Hort. 367:440.

Drake, S.R. 1989. Harvest indicators. Proc. Wash. State Hort. Assn. 85:196-197.

Fallahi, E., and F.E. Larsen. 1981. Rootstock influences on 'Bartlett' and 'd'Anjou' pear fruit quality at harvest and after storage. HortScience 16:650-651.

Hansen, E., and Mellenthin, W.M. 1979. Commercial handling and storage practices for winter pears. Ore. State Univ. Agr. Expt. Sta. Spec. Rpt. 550.

Hunter, R.S. and R.W. Harold. 1987. The measurement of appearance. 2nd ed. Wiley, New York.

Kvale, A. 1990. Maturity indexes for pears. Acta Hort. 285:103-109.

Meheriuk, M. 1988. Harvest maturity and storage regime for pears. Post. Pomol. Nwslt. 6:(3).

Meheriuk, M. 1989. Storage characteristics of Spartlett pear. Acta Hort. 258:215-219.

Looney N.E. 1972. Interaction of harvest maturity, cold storage and two growth regulators on ripening of 'Bartlett' pears. J. Amer. Soc. Hort. Sci. 97:81-83.

SAS 1999. SAS User's guide: Statistics. version 8.0. 1999. SAS Inst., Cary, N.C.

Sugar, D. and P.B. Lombard. 1989. Harvest sequence, storage life and marketing periods for red pear cultivars in the Pacific Northwest region of the United States. Acta Hort. 256: 231-233.

Sugar, D. and K.A. Powers. 1994. Maturity and storage performance of 'Bartlett' and 'Sensation Red Bartlett' pears. HortScience 29:18-19.

Talley, E. 1989. Harvest maturity affects pear market quality. Proc. Wash. State Hort. Assn. 85:197.

Testoni, A, F., Lovati, M. Grassi, and R. Lo Scalzo. 2002. Storage of 'Conference' pear in low ethylene atmosphere. Acta Hort. 596: 895-898.

Tvergyak, P.J. 1985. Pear maturity indexes used to time harvest date. Post. Pomol. Nwslt. 3(3).

Xuan, H., J. Streif, and F. Bangerth. 2002. Does boron affect the occurrence of physiological disorders of 'Conference' pears during CA-storage? Acta Hort. 596:857-862. 